\title{
A New Eastern Limit of the Pacific Flying Fox, Pteropus tonganus (Chiroptera: Pteropodidae), in Prehistoric Polynesia: A Case of Possible Human Transport and Extirpation ${ }^{1}$
}

\author{
Marshall I. Weisler, ${ }^{2}$ Robert Bollt, ${ }^{3}$ and Amy Findlater ${ }^{4}$
}

\begin{abstract}
Five bones, representing one adult of the Pacific Flying Fox, Pteropus tonganus, were recovered from an archaeological site on Rurutu $\left(151^{\circ} 21^{\prime} \mathrm{W}, 22^{\circ}\right.$ $27^{\prime} \mathrm{S}$ ), Austral Islands, French Polynesia, making this the most eastern extension of the species. For the first time, flying fox bones from cultural deposits were directly dated by accelerator mass spectrometry, yielding an age of death between A.D. 1064 and 1155. Their stratigraphic position in an Archaic period archaeological site and the absence of bones in the late prehistoric to historic layers point to extirpation of the species. No flying fox bones were found in prehuman deposits and human transport of the species cannot be ruled out.
\end{abstract}

DURING THE PAST few decades archaeozoology (the study of animal bones from archaeological sites) has made important contributions to island biogeography by recovering bones of birds previously unknown to science (Steadman 1995), extending the range of extant species (Wragg 1995), and understanding the dynamic relationships of people, fauna, and flora within Pacific island ecosystems during the late Pleistocene and throughout the Holocene. It is now relatively commonplace to document human-caused avian extinctions on high volcanic islands such as Hawai'i (Olson and James 1982, Burney et al. 2001), the large continental islands of New Zealand (Anderson 1989, Worthy 1998), makatea landforms in the southern Cooks (Steadman and Kirch 1990) and Henderson, Pitcairn Islands (Wragg and Weisler

${ }^{1}$ This project was supported by a National Science Foundation doctoral dissertation improvement grant (No. BCS04-37581) to R.B. Manuscript accepted $3 \mathrm{Au}-$ gust 2005.

${ }^{2}$ School of Social Science, University of Queensland, St. Lucia 4072, Queensland, Australia.

${ }^{3}$ Department of Anthropology, University of Hawai' $i$ at Mānoa, Honolulu, Hawai'i 96822.

${ }^{4}$ Department of Anthropology, University of Otago, Dunedin, New Zealand.

Pacific Science (2006), vol. 60, no. 3:403-411

(C) 2006 by University of Hawai'i Press

All rights reserved
1994), and possibly low coral atolls (Weisler 2001). In essence, no insular landscape was immune from the effects of colonizing humans who cleared land for horticulture (Kirch 1983, Athens and Ward 1993) and introduced commensal animals such as pigs, dogs, chickens, and rats (Green and Weisler 2004, Matisoo-Smith and Robins 2004) as well as vital cultigens, including medicinal and ornamental plants (Barrau 1963, Yen 1973, Kirch 1982).

In this paper we report what is now the most easterly occurrence of the Pacific Flying Fox (Pteropus tonganus), recovered from archaeological deposits dating to as early as the eleventh century A.D. on Rurutu $\left(151^{\circ} 21^{\prime}\right.$ $\mathrm{W}, 22^{\circ} 27^{\prime} \mathrm{S}$ ), one of the seven Austral Islands, located $\sim 470 \mathrm{~km}$ south of Tahiti in central East Polynesia (Figure 1). The sample size of five bones represents at least one adult individual. Their stratigraphic position in an Archaic period archaeological site, and the distance of Rurutu from documented populations of flying foxes in the southern Cook Islands, $\sim 600 \mathrm{~km}$ to the west, may suggest human introduction. No flying fox bones were recovered in prehuman deposits, and the small number of bones in the oldest cultural layer suggests that the Pteropus population was never very large. We also provide the first direct radiocarbon age determinations on Pacific Flying Fox from prehistoric contexts and discuss some probable causes of its extirpation on Rurutu. 


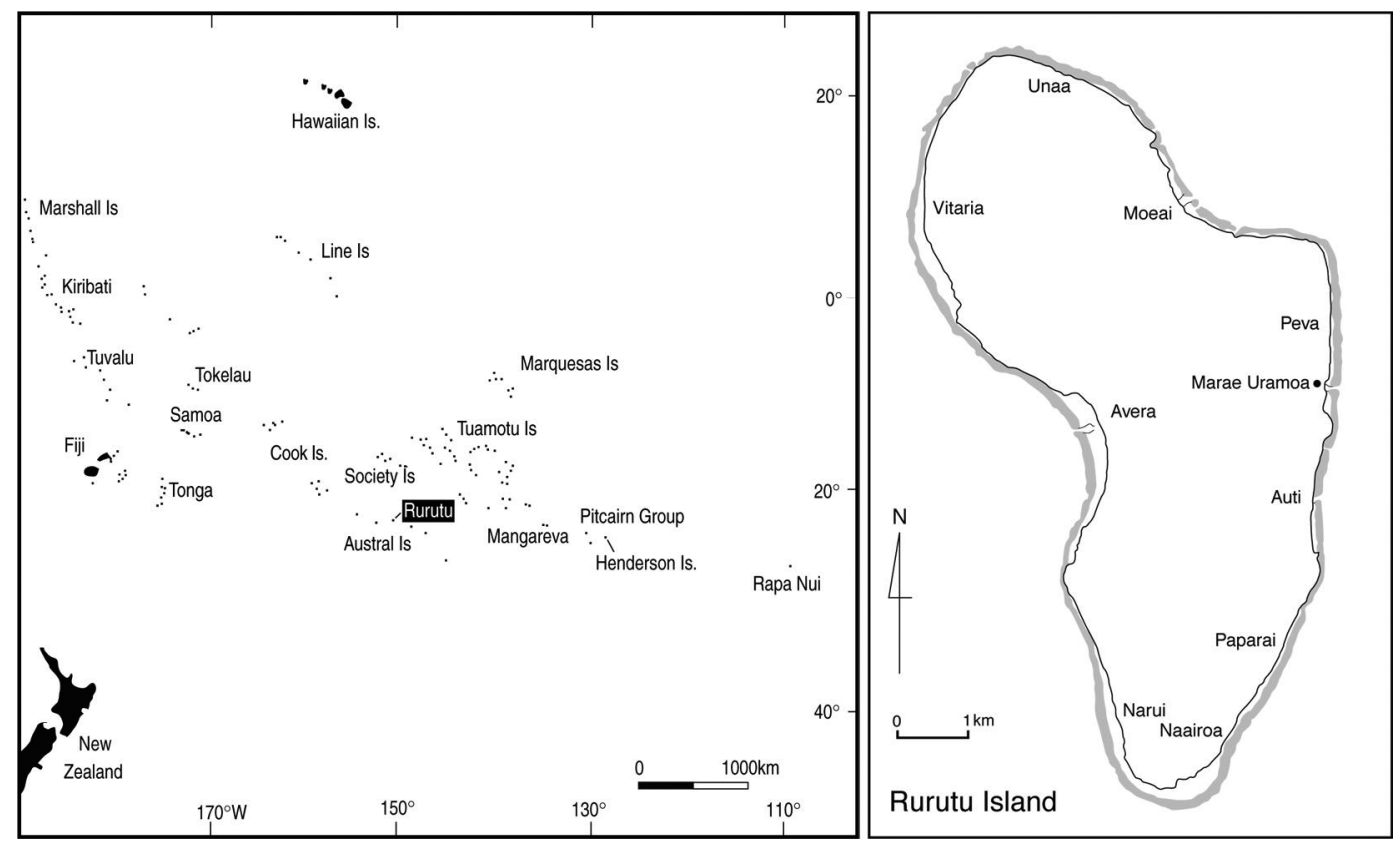

FIgURE 1. Map showing the location of Rurutu in the Austral Islands. The archaeological excavations were conducted at Marae Uramoa near a pass, just south of Peva on the east coast.

The Pacific Flying Fox is one of the most widespread Pteropus species and is currently found from the Solomon Islands to the southern Cook Islands (Flannery 1995, Miller and Wilson 1997). Martin (1968) documented that flying foxes were taken to Tahiti in the midnineteenth century, and Flannery (1995) believes that because Polynesians carried flying foxes as pets it is possible that some populations result from introductions. This is merely the historic continuation of midHolocene introductions of animals by humans in island Melanesia that extended species beyond their natural range (Flannery et al. 1988). Our contention here is that $P$. tonganus may have been transported from the southern Cook Islands to the Australs sometime during the eleventh century A.D. Direct transfer is unlikely because the first appreciable landfall from the southern Cooks is Rimatara, some $150 \mathrm{~km}$ west of Rurutu, although no records of flying foxes are known from there. This opens up the possibility that prehistoric records of flying foxes may be discovered in other islands in the Australs.
Ethnographic and Archaeological Evidence of the Flying Fox in Polynesia

The Pacific Flying Fox was clearly a food item, although it was considered sacred on some islands. Beginning in Uvea, West Polynesia, the flying fox was sometimes captured by shaking the branches from which it hangs to sleep, although by 1932 it was only taken with shotguns (Burrows 1937). During his fieldwork in Tonga during 1920-1921, Gifford (1929) recorded that the flying fox was still considered a deity on Tongatapu. In Tutuila, Samoa, Buck (1930) reported that flying foxes $\left(p e^{\prime} a\right)$ were caught at night in a fowling net with a long handle as they flew low to the ground; occasionally they were hunted with bow and arrow. Polynesians built permanent platforms in the tops of tall trees in Niue where, in the late afternoon, a snare was used to trap a flying fox (peka) that was used as a decoy to attract other individuals that were caught in a net. Up to 200 could be captured in one night (Loeb 1926). There is also a Niuean legend that describes how the flying 
fox carries her "children" clinging to her breast instead of leaving them behind in the nest like a pigeon (Loeb 1926). Henry's (1928) major treatise on ancient Tahiti was based on observations made by Reverend Orsmond in the early nineteenth century and no mention was made of the flying fox, suggesting that it was of little importance, extirpated, or perhaps never present prehistorically. The flying fox was, however, a mid-nineteenth-century introduction (Martin 1968). The Pacific Flying Fox is thought to be indigenous to the southern Cook Islands, where historically it is known from Mangaia and Rarotonga (Hill 1979, Flannery 1995), which, until now, was thought to be the eastern limit of the species. F. Alan Seabrook, who did extensive ethnographic fieldwork on Rurutu in the 1930s, stated (1938), "The Cook Islands bat did not reach Rurutu." By the early 1920s, there was no record of the flying fox in Tubuai, Austral Islands, when Aitken (1930) spent eight months inventorying the flora, fauna, and customs.

The published archaeological occurrence of Pacific Flying Fox in Polynesia is limited to Tonga, Niue, and the southern Cook Islands. On 'Eua, southern Tonga, Koopman and Steadman (1995) recovered 17 bones of $P$. tonganus (including a mandible, lower incisor, three radii, three metacarpals, seven manal phalanges, a femur, and a tibia) from excavations at three limestone caves. Only one of these bones was reported as coming from prehuman deposits, and two specimens were from the cultural layer in 'Anatú cave dated to $570 \pm 70$ to $2710 \pm 70$ B.P. (Koopman and Steadman 1995). An additional 17 specimens were mostly fragmentary and may represent either $P$. tonganus or $P$. samoensis (Koopman and Steadman 1995). On the $m a-$ katea island of Niue, 11 bones and one tooth of $P$. tonganus were recovered from surface and excavated layers from one archaeological and one "non-cultural" context (Worthy et al. 1998, Worthy et al. 2002). None of the bones or contexts was dated, but eight of the bones from surface and excavated deposits at Ulupaka Cave, south entrance, are assumed to be of archaeological origin (Worthy et al. 1998; T. Worthy, pers. comm., 2005). We agree with Worthy's conclusion that the Niue bones are contemporaneous with prehistoric occupation but do not provide evidence for prehuman existence of fruit bats on the island, although it could well be an indigenous taxon based on its widespread occurrence throughout the Southwest Pacific (T. Worthy, pers. comm., 2005). Three of the southern Cook Islands have prehistoric records of $P$. tonganus (known locally as moa kirikiri). From the west coast of Aitutaki, a sandy archaeological deposit dating to $<1000$ B.P. contained a molar and wing phalanx (Steadman 1991). Walter (1998) found a single flying fox mandible in an Archaic period deposit on Ma'uke, and the small quantity of flying fox bone suggests that the taxon was extirpated soon after human occupation. The most extensive assemblage of Pacific Flying Fox bones from any prehistoric site in Polynesia was recovered from a habitation rockshelter on Mangaia from layers dating to the eleventh to fourteenth centuries (Steadman and Kirch 1990). The frequency of the bones at the site diminishes over time, suggesting local depression of the population. There is no evidence of flying fox bones in the Cook Islands before human occupation, but, as on Niue, we would expect indigenous populations. These sites of the southern Cook Islands are contemporaneous with one another, as well as with the site on Rurutu-all dating to the Archaic period of East Polynesia, when most insular extinctions took place.

\section{The Study Area}

The Austral Islands of French Polynesia include the volcanic islands Rimatara, Rurutu, Tubuai, Raivavae, Rapa, and two uninhabited islets, Maria (formerly Hull), an atoll, and the small isolated rock spires of Marotiri. The Australs have the smallest total landmass $\left(144 \mathrm{~km}^{2}\right)$ of any East Polynesian archipelago except the Pitcairn group $\left(43 \mathrm{~km}^{2}\right)$. Although high islands, their elevation is not sufficient to produce orographic rain. The Australs are the southernmost archipelago in French Polynesia, lying across the Tropic of Capricorn. The average yearly temperature is $23.1^{\circ} \mathrm{C}$ with an average annual rainfall of $1,848 \mathrm{~mm} / \mathrm{yr}$ 
(ORSTOM 1993). Distances of approximately $150-200 \mathrm{~km}$ separate the islands from each other.

The nearest neighbors of Rurutu, our study island, are Tubuai, $225 \mathrm{~km}$ to the east, and Rimatara, $150 \mathrm{~km}$ distant. Rurutu has a landmass of $32.3 \mathrm{~km}^{2}$ and a maximum elevation of $389 \mathrm{~m}$. It consists of a volcanic core, ringed by makatea limestone, which faces the sea in escarpments up to $100 \mathrm{~m}$ high. These cliffs subdivide the island into valleys. The vegetation of Rurutu was exceptionally impoverished compared with that of most other Polynesian high islands by the time of European contact in the late eighteenth century. Its barren landscape prompted Joseph Banks (1962) to write in 1769, "The Island to all appearance that we saw was more barren than any thing we have seen in these seas." The small coastal plains that border the island consist of sand and coral debris. Rurutu's fringing reef is generally small and straight with neither a lagoon nor a barrier reef. The reef flats are for the most part $100 \mathrm{~m}$ wide but not uniform around the island (Pirazzoli and Salvat 1992).

\section{MATERIALS AND METHODS}

From May to August 2003, R.B. excavated an Archaic East Polynesian site in the sector of Peva Rahi, Peva Valley, on the east coast of Rurutu (Figure 1). The excavation took place on the grounds of the marae (temple) "Uramoa," constructed atop a coastal sand dune, on the terrain known as Onatietie. It is situated approximately $100 \mathrm{~m}$ from the coast in an overgrown section of unused private land. The dune extends the entire 1-km length of Peva Iti. All sediments were dry-screened using 1/8-inch (3.2-mm) mesh. Further details of the excavations are presented in Bollt (2005).

\section{Radiocarbon Dating}

Pacific Flying Fox bones have never been directly dated. In most examples, Pteropus has been dated through its association with prehistoric artifacts, food remains, and cooking stones in cultural layers where charcoal from in situ combustion features or carbonized wood dispersed throughout deposits has been radiocarbon dated (e.g., Steadman and Kirch 1990). Because Pteropus roosts primarily in trees (Miller and Wilson 1997), it is possible that bones could enter archaeological sites through natural death and not as human food refuse (Weisler and Gargett 1993). Consequently, we selected the two radii fragments of $P$. tonganus for accelerator mass spectrometry (AMS) age determinations. The samples were processed at the National Ocean Sciences Accelerator Mass Spectrometry Facility (NOSAMS), Woods Hole Oceanographic Institution, Woods Hole, Massachusetts. The Pacific Flying Fox bones were processed using organic combustion to produce $\mathrm{CO}_{2}$. Collagen was extracted from each bone using the EDTA (ethylenediaminetetraacetic acid) method. The collagen was then combusted and converted to graphite.

\section{RESULTS}

The material recovered from the marae "Uramoa" site excavation includes typical Archaic East Polynesian artifacts such as untanged adzes and one-piece pearl-shell fishhooks. The excavation yielded abundant faunal remains (mostly fish, but also turtle and pig, with lesser quantities of rat and bird) and charcoal from earth ovens in intact stratigraphic layers representing two distinct cultural occupations. The lower layer D $(\sim 80$ $110 \mathrm{~cm}$ below surface) represents a habitation site from the Archaic period (beginning as early as the eleventh century A.D. and continuing until ca. A.D. 1400), and the upper layer A (0-20 cm below surface), associated with the marae, is from the Classic/Early Historic period (late eighteenth to early nineteenth century A.D. [Figure 2]).

The Pacific Flying Fox bones are from units G10 and G11, layer D of the excavation site and consist of one proximal end and one distal end of the right radius that do not fit together but have a combined length of $\sim 150 \mathrm{~mm}$, which is within the range of variability of the forearm length range of $P$. tonganus as recorded by Flannery (1995); one index claw; and one left mandible (Figure 3). 
At least one adult individual is represented. Trevor Worthy identified the flying fox mandible, and R.B. identified four other bones with a Pteropus reference specimen held at

\section{G13/14}

East Profile

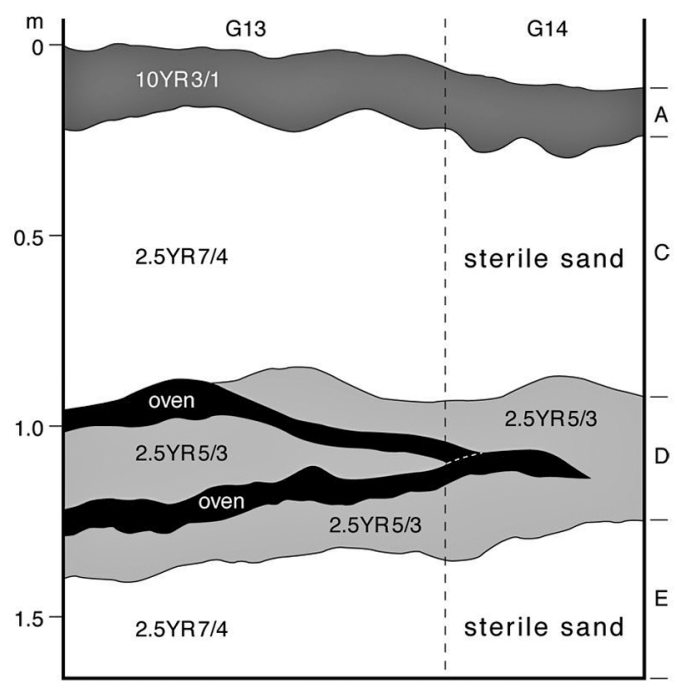

Figure 2. A typical stratigraphic profile of the Marae Uramoa site showing prehistoric cultural layers A and D. The lowest cultural layer contained bones of the Pacific Flying Fox, Pteropus tonganus. G13 and G14 refer to excavation units. Designations such as $10 \mathrm{YR} 3 / 1 \mathrm{refer}$ to Munsell soil/sediment colors, generally from dark (upper layer) to lighter (lower layers). the Department of Anthropology, University of Hawai'i at Mānoa.

Table 1 presents the results of the agedetermination analysis. Samples were calibrated with Reimer et al. (2004) for terrestrial samples after subtracting $10 \mathrm{yr}$ from the mean for Southern Hemisphere material (Stuiver et al. 1998). Because the two samples are likely from the same individual, we averaged the calibrated ages (Reimer et al. 2004), and there is a $74 \%$ probability that the age of death of the flying fox was between A.D. 1064 and 1155. However, it must be noted that these dates are approximately $200 \mathrm{yr}$ older than the average of six charcoal dates (on unidentified wood) from the same cultural layer (Bollt 2005). This discrepancy may be due to postdepositional contamination of the bone samples (Hedges and Van Klinken 1992). Considering all eight radiocarbon age determinations, however, the deposit is securely within the Archaic period, when similar extinction and extirpation events occurred throughout East Polynesia.

\section{DISCUSSION AND CONCLUSIONS}

The suggestion by Flannery (1995) that humans may have been a dispersal agent for the Pacific Flying Fox seems possible with the identification of the five bones of this taxon from the archaeological site at Peva, Rurutu, in the Austral Islands-now the most easterly

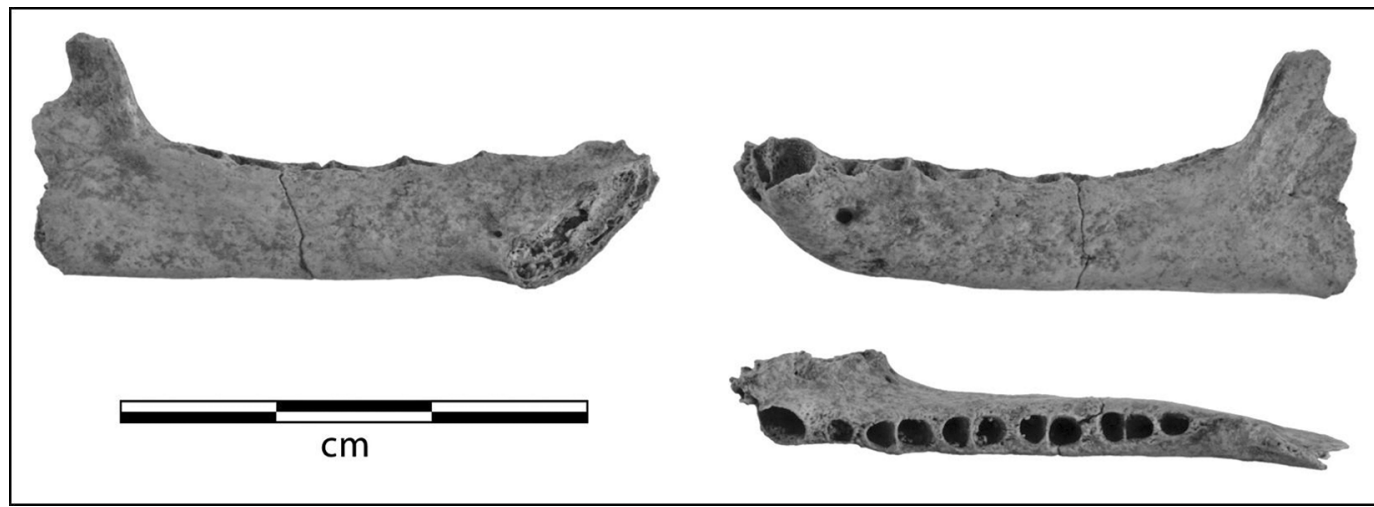

Figure 3. The left mandible of Pacific Flying Fox (Pteropus tonganus), seen in superior, lateral, and medial views. 
TABLE 1

Radiocarbon Age Determinations for Pacific Flying Fox Bones from the Peva Site, Unit G10, Layer D

\begin{tabular}{lcccc}
\hline \hline Lab. No. & & $\begin{array}{c}2 \sigma \text { Cal Age } \\
\text { Ranges A.D. }\end{array}$ & $\begin{array}{c}\text { Relative Area } \\
\text { under Distribution }\end{array}$ \\
\hline NOSAMS48011 & ${ }^{14} \mathrm{C}$ Age yr B.P. & ${ }^{13} \mathrm{C} /{ }^{12} \mathrm{C}$ & $990-1048$ & 0.50 \\
& $995 \pm 35$ & -18.22 & $1087-1122$ & 0.38 \\
NOSAMS48049 & & & $1138-1150$ & 0.11 \\
\hline
\end{tabular}

known extent of the species. Only one bone of $P$. tonganus has been recovered from prehuman contexts in the whole of Polynesia; Koopman and Steadman (1995) reported the find from Tonga. The Pacific Flying Fox has not been found in prehuman contexts on Niue, the Cook Islands, or Rurutucurrently the only other archaeological occurrences of the species in Polynesia. We agree with Flannery that human translocation of the flying fox leading to establishment of a thriving population seems unlikely ( $\mathrm{T}$. Flannery, pers. comm., 2005), especially given the archaeological records for Ma'uke and Rurutu, where the flying fox was extirpated soon after human occupation. Given its biogeographic history, it is likely that the flying fox dispersed to the eastern margins of its range unaided by humans, but we strongly advocate direct dating of flying fox bones to clearly document the occurrence of Pteropus before human settlement.

The flying fox is not known from prehistoric deposits in the Society Islands, yet future excavations using fine-mesh sieves may recover bones of this species: the distance from the southern Cook Islands to the Australs and the high islands of the Societies (with favorable habitats) is quite similar. The Tuamotus emerged only during the late Holocene (Dickinson 2004), and, consequently, flying fox could not use these islands as "stepping stones" to Mangareva $(\sim 1,400 \mathrm{~km}$ from the Australs) or to the Marquesas $(\sim 1,800$ $\mathrm{km}$ ), both of which do not have records of flying fox. However, it is unlikely that flying foxes could have made such long water crossings. Composed of low coral atolls and one uplifted makatea island, the Tuamotus are generally unsuitable habitat for flying foxes and may have been a natural barrier that prevented the further eastern extension of the species.

The five bones recovered from Rurutu are probably from the same adult individual, and direct radiocarbon age determinations yield a time of death during the mid-eleventh to twelfth centuries, or perhaps to the fourteenth century if wood charcoal dates are a more reliable indication. Despite intensive excavations covering $46.5 \mathrm{~m}^{2}$ of the site, no other flying fox bones were recovered, suggesting that this species was never common on Rurutu during the Archaic periodassuming that it was a desirable food item. That no flying fox bones were recovered from a large excavated sample in the late prehistoric/Early Historic layer A suggests that $P$. tonganus was extirpated-although additional archaeological sites on Rurutu with similar stratigraphic evidence would provide a clearer picture of the process of extirpation. The paucity of bird bones in layer A also documents that other endemic species had been drastically diminished by the fourteenth century A.D.

Due to the relatively impoverished nature of the Rurutu vegetation by the late eighteenth century, as reported by early European visitors, it is likely that deforestation played a major role in the extirpation of the flying fox on the island. With their low reproductive rate, these animals are very sensitive to overhunting, introduced predators and competitors (such as the Pacific rat, Rattus exulans), and, most important, habitat loss (Miller and Wilson 1997). Rurutu is relatively low in altitude for a high island, and the vast majority 
of its terrain is easily accessible on foot. On such an island, mass deforestation could have occurred quickly after human settlement-a scenario that was played out on many islands across the Pacific (Rolett and Diamond 2004).

Although human predation is clearly a major reason for the disappearance of flying foxes in Samoa (Craig et al. 1994) and probably most oceanic islands, small insular populations are also very susceptible to abrupt landscape changes, whether human induced (Kirch 1983) or the result of drought or hurricanes (Craig et al. 1994). These climatic perturbations must be considered when determining the causes of insular extirpations and extinctions, and it is noteworthy that drought is not an important problem in the Australs, but hurricanes have been known to do considerable damage historically. Forest clearance by humans caused increased erosion and greatly reduced the food supply for indigenous species and available roosts or nesting sites. The Pacific rat, also introduced by humans across Oceania (Matisoo-Smith and Robins 2004), was an important predator of ground-nesting birds (Brooke 1995), and it may have competed for similar vegetarian foods of flying foxes. Humans undoubtedly contributed both directly (through predation and habitat destruction) and indirectly (by the introduction of a potential competitor, the Pacific rat) to the extirpation of the $\mathrm{Pa}$ cific Flying Fox on Rurutu.

Because the Pacific Flying Fox is a generalist forger that feeds on fruit, it disperses seeds and acts as a pollinator. In this capacity, it may aid plants in the colonization of an island (Elmqvist et al. 1992) and disperse seeds to regenerate areas affected by hurricanes. In essence, the Pacific Flying Fox is a good "barometer" of the overall health of an island. The extirpation of the species is one of many signals that an island underwent stress from human-induced and natural phenomena (e.g., hurricanes and drought).

\section{ACKNOWLEDGMENTS}

R.B. thanks the National Science Foundation for supporting his research; Pierre Vérin for introducing him to Rurutu; the community of Rurutu and specifically its mayor, Frédéric Rivéta, as well as the site landowner, Fernand Roomataaroa; his hosts on the island, Pierre Atai, Ingride Drollet, and their sons Takiri and Tapu; Rurutu's Minister of Tourism, Yves Gentilhomme; the government of French Polynesia, its former Ministre de la Culture, Louise Pelzter, and Henri Marchesi of the Service de la culture et du Patrimoine and the Musée de Tahiti et ses Iles; and especially his assistant on Rurutu, Papua. We thank Trevor Worthy for identifying the flying fox mandible. We appreciate the helpful comments made by Carl Christensen and David Steadman. Les O'Neill and Michael Haslam prepared the figures.

\section{Literature Cited}

Aitken, R. T. 1930. Ethnology of Tubuai. Bernice P. Bishop Mus. Bull. 70.

Anderson, A. 1989. Prodigious birds: Moas and moa-hunting in prehistoric New Zealand. Cambridge University Press, Cambridge.

Athens, J. S., and G. Ward. 1993. Environmental change and prehistoric Polynesian settlement in Hawai'i. Asian Perspect. 32:205-224.

Banks, J. 1962. The Endeavor journal of Joseph Banks, 1768-1771, ed. J. C. Beaglehole. Angus and Robertson, Sydney.

Barrau, J., ed. 1963. Plants and the migrations of Pacific peoples: A symposium. Bishop Museum Press, Honolulu.

Bollt, R. 2005. Peva: The archaeology of a valley on Rurutu, Austral Islands. Ph.D. diss., University of Hawai'i at Mānoa, Honolulu.

Brooke, M. deL. 1995. The breeding biology of the gadfly petrels Pterodroma spp. of the Pitcairn Islands: Characteristics, population sizes and controls. Biol. J. Linn. Soc. 56:213-231.

Buck, P. H. (Te Rangi Hiroa). 1930. Samoan material culture. Bernice P. Bishop Mus. Bull. 75.

Burney, D. A., H. F. James, L. P. Burney, S. L. Olson, W. Kikuchi, W. L. Wagner, M. Burney, D. McCloskey, D. Kikuchi, F. V. Grady, R. Gage, and R. Nishek. 
2001. Fossil evidence for a diverse biota from Kaua' $i$ and its transformation since human arrival. Ecol. Monogr. 71:615-641.

Burrows, E. G. 1937. Ethnology of Uvea (Wallis Island). Bernice P. Bishop Mus. Bull. 145.

Craig, P., P. Trail, and T. E. Morrell. 1994. The decline of fruit bats in American Samoa due to hurricanes and overhunting. Biol. Conserv. 69:261-266.

Dickinson, W. R. 2004. Impacts of eustasy and hydro-isostasy on the evolution and landforms of Pacific atolls. Palaeogeogr. Palaeoclimatol. Palaeoecol. 213:251-269.

Elmqvist, T., P. A. Cox, W. E. Rainey, and E. D. Pierson. 1992. Restricted pollination on oceanic islands: Pollination of Ceiba pentandra by flying foxes in Samoa. Biotropica 24:15-23.

Flannery, T. 1995. Mammals of the Southwest Pacific and Moluccan Islands. Cornell University Press, Ithaca, New York.

Flannery, T., P. V. Kirch, J. Specht, and M. Spriggs. 1988. Holocene mammal faunas from archaeological sites in island Melanesia. Archaeol. Oceania 23:89-94.

Gifford, E. W. 1929. Tongan society. Bernice P. Bishop Mus. Bull. 61.

Green, R. C., and M. I. Weisler. 2004. Prehistoric introduction and extinction of animals in Mangareva, Southeast Polynesia. Archaeol. Oceania 39:34-41.

Hedges, R. E. M., and G. J. Van Klinken. 1992. A review of current approaches in the pretreatment of bone for radiocarbon dating by AMS. Radiocarbon 34:279-291.

Henry, T. 1928. Ancient Tahiti. Bernice P. Bishop Mus. Bull. 48.

Hill, J. E. 1979. The Flying Fox Pteropus tonganus in the Cook Islands and on Niue Island, Pacific Ocean. Acta Theriol. 24:115122.

Kirch, P. V. 1982. The impact of the prehistoric Polynesians on the Hawaiian ecosystem. Pac. Sci. 36:1-14.

. 1983. Man's role in modifying tropical and subtropical Polynesian ecosystems. Archaeol. Oceania 18:26-31.

Kirch, P. V., J. R. Flenley, D. W. Steadman, F. Lamont, and S. Dawson. 1992. Ancient environmental degradation. Natl. Geogr. Res. Explor. 8:166-179.
Koopman, K. F., and D. W. Steadman. 1995. Extinction and biogeography of bats on 'Eua, Kingdom of Tonga. Am. Mus. Novit. 3125.

Loeb, E. M. 1926. History and traditions of Niue. Bernice P. Bishop Mus. Bull. 32.

Martin, H. B. 1968. The Polynesian journal of Captain Henry Byam Martin. Australian National University Press, Canberra.

Matisoo-Smith, E., and J. H. Robins. 2004. Origins and dispersals of Pacific peoples: Evidence from $\mathrm{mtDNA}$ phylogenies of the Pacific rat. Proc. Natl. Acad. Sci. U.S.A. 101:9167-9172.

Miller, C. A., and D. E. Wilson. 1997. Pteropus tonganus. Mamm. Species 552:1-6.

Olson, S. L., and H. F. James. 1982. Fossil birds from the Hawaiian Islands: Evidence for wholesale extinction by man before Western contact. Science (Washington, D.C.) 217:633-635.

ORSTOM. 1993. Atlas de la Polynésie française. Papeete.

Pirazzoli, P. A., and B. Salvat. 1992. Ancient shorelines and Quaternary vertical movements on Rurutu and Tubuai (Austral Isles, French Polynesia). Z. Geomorphol. N. F. 36 (4): 431-451.

Reimer, P. J., M. G. L. Baillie, E. Bard, A. Bayliss, J. W. Beck, C. J. H. Bertrand, P. G. Blackwell, C. E. Buck, G. S. Burr, K. B. Cutler, P. E. Damon, R. L. Edwards, R. G. Fairbanks, M. Friedrich, T. P. Guilderson, A. G. Hogg, K. A. Hughen, B. Kromer, G. McCormac, S. Manning, C. B. Ramsey, R. W. Reimer, S. Remmele, J. R. Southon, M. Stuiver, S. Talamo, F. W. Taylor, J. Van Der Plicht, and C. E. Weyhenmeyer. 2004. IntCal04 terrestrial radiocarbon age calibration $0-26 \mathrm{cal} \mathrm{kyr}$ B.P. Radiocarbon 46:1029-1058.

Rolett, B., and J. Diamond. 2004. Environmental predictors of pre-European deforestation on Pacific islands. Nature (Lond.) 431:443-446.

Seabrook, F. A. 1938. Rurutuan culture. Manuscript. Bernice P. Bishop Museum, Honolulu.

Steadman, D. W. 1989. Extinction of birds in eastern Polynesia: A review of the record, and comparisons with other Pacific Island groups. J. Archaeol. Sci. 16:177-205. 
1991. Extinct and extirpated birds from Aitutaki and Atiu, southern Cook Islands. Pac. Sci. 45:325-347.

—. 1995. Prehistoric extinctions of Pacific Island birds: Biodiversity meets zooarchaeology. Science (Washington, D.C.) 267:1123-1131.

Steadman, D. W., and P. V. Kirch. 1990. Prehistoric extinction of birds on Mangaia, Cook Islands, Polynesia. Proc. Natl. Acad. Sci. U.S.A. 87:9605-9609.

Stuiver, M., P. J. Reimer, E. Bard, G. S. Burr, K. A. Hughen, B. Kromer, F. G. McCormac, T. V. D. Plicht, and M. Spurk. 1998. INTCAL98 radiocarbon age calibration, 24,000 cal BP. Radiocarbon 40:10411083.

Walter, R. 1998. Anai'o: The archaeology of a fourteenth century Polynesian community in the Cook Islands. N. Z. Archaeol. Assoc. Monogr. 22.

Walter, R., and A. Anderson. 2002. The archaeology of Niue Island, West Polynesia. Bishop Mus. Bull. Anthropol. 10.

Weisler, M. I. 2001. On the margins of sustainability: Prehistoric settlement of Utrōk Atoll, northern Marshall Islands. BAR International Series 967. Archaeopress, Oxford.
Weisler, M. I., and R. Gargett. 1993. Pacific island avian extinctions: The taphonomy of human predation. Archaeol. Oceania 28:85-93.

Worthy, T. 1998. A remarkable fossil and archaeological avifauna from Marfells Beach, Lake Grassmere, South Island, New Zealand. Rec. Canterbury Mus. 12:79-176.

Worthy, T., R. Walter, and A. Anderson. 1998. Fossil and archaeological avifauna of Niue Island, Pacific Ocean. Notornis 45:177-190.

Worthy, T., A. Anderson, and R. Walter. 2002. Appendix D. Fossil fauna from Niue Island. Pages 165-167 in R. Walter and A. Anderson, The archaeology of Niue Island, West Polynesia. Bishop Mus. Bull. Anthropol. 10.

Wragg, G. 1995. The fossils birds of Henderson Island, Pitcairn Group: Natural turnover and human impact, a synopsis. Biol. J. Linn. Soc. 56:405-414.

Wragg, G., and M. I. Weisler. 1994. Extinction and new records of birds from Henderson Island, Pitcairn Group, South Pacific Ocean. Notornis 41:61-70.

Yen, D. E. 1973. The origins of Oceanic agriculture. Archaeol. Phys. Anthropol. Oceania 8:68-85. 
